\title{
Antidiabetic bioactive compounds from plants
}

\section{Type of article: Review}

\author{
Missoun Fatiha ${ }^{1}$, Bouabdelli Fatma ${ }^{1}$, Baghdad Awatif ${ }^{2}$, Amari Nesrine ${ }^{1}$, Djebli \\ Noureddine ${ }^{1}$. \\ 1Laboratory of Pharmacognosy and Api-Phytothérapy (LPAP), University of \\ Mostaganem.
}

Algeria.

2Department of chemistry, University of Mostaganem.

Algeria

\begin{abstract}
Diabetes mellitus is a common and widespread disease that affects citizens in developed and developing countries. Diabetes is a disease that combines inherited and environmental causes that cause high blood sugar levels known as hyperglycemia. Phytotherapy has achieved good clinical practice and shows a bright future in the treatment of diabetes mellitus. The purpose of this review was to provide information about the most useful antidiabetic compounds from plants available through numerous literature sources from various databases. Many researches confirmed the benefits of phytoconstituants with antidiabetic effects in the management of diabetes mellitus. Thus, drugs from plants may control all pathological aspects of diabetes, either by increasing insulin production by the pancreas, helping to lower the body's insulin requirements, or reducing gluconeogenesis in the liver. The effect of these antidiabetic plants has been tested in vivo and in vitro on rats, mice, rabbits and dogs. Very few have been tested on humans for their effectiveness.
\end{abstract}

Keywords : Diabetesmellitus ; phytochemicals ; glucose ; $\beta$-cells; insulin secretion; Metabolicdisorder.

Corresponding author: Missoun fatiha, Laboratory of Pharmacognosy and Api-Phytothérapy (LPAP), University of

Mostaganem, Algeria. Email: fatiha.missoun@univ-mosta.dz Tel: (00213)664981875

Received: March 22, 2018, Accepted: Mai 27, 2018, English editing: June 3, 2018, Published: 27 June, 2018.

Screened by iThenticate.(2017-2018 KNOWLEDGE KINGDOM PUBLISHING.

\section{Introduction}

Diabetes is a chronic disease characterized by hyperglycemia (high levels of glucose or sugar in the blood), abnormal metabolism of proteins and lipids. Chronic metabolic imbalance caused by this disease puts patients at high risk of long-term serious health problems, especially cardiovascular problems [1], Diabetics are estimated to be more than 347 million people worldwide and is expected to become the 7th leading cause of death by 2030(WHO, Diabetes Program. http://www.who.int/diabetes/en/ (2012)).

There are two types of diabetes mellitus: Insulin-dependent diabetes or type I diabetes, non-insulin-dependent diabetes or type II diabetes. In Type I diabetes or juvenile diabetes, pancreatic beta cells produce very little or no insulin because of an autoimmune reaction that destroys them partially or completely, and is known to affect only $10 \%$ of the diabetic population. The Type II, is a complex endocrine and metabolic disorder which is non-insulin dependent, characterized by chronic hyperglycemia. This disease usually occurs in older adults and affects more the obese or overweight people [2,3]. No treatment can cure diabetes permanently. Antidiabetic medications, all of which have the effect of lowering blood glucose or helping to control it by reducing insulin resistance, or increasing insulin secreted by the pancreas by different mechanisms [4]. 
The outlook for diabetic patients today are much better than before because of the development of different types of antidiabetic drugs. Plants are a good source of new bioactive molecules. Many phytochemicals with antidiabetic effects have been isolated from plants but hypoglycemic activity mechanisms of these plants are still in progress [5].

The purpose of this review is to provide an overview of the efficacy of some phytochemicals used to treat diabetes. Scientific research on natural compounds from plants for diabetes may provide valuable leads for the development of alternative medicines and therapeutic strategies.

\section{Methods}

Information about phytochemicals and medicinal plants traditionally used to treat diabetes cited in this review were obtained from more than 500 published papers and ethnobotanical studies. The search was carried out on different databases including Science Direct, Springer, Scopus, PubMed, Web of Science and Google Scholar using "Diabetes mellitus", "antidiabetic medicinal plants", "hypoglycemic plants" "phytoconstituents" and" phytochemicals for diabetes management" as keys words. Data were collected from 2013 to 2016.English and French languages were used in this research. Experimental research and clinical trials that evaluate the effect of the bioactive component in diabetic animals or patients have been included in this research. The importance of phytochemicals has been materialized by their usual value. On this basis, some drugs have proven to be more important than others (table 1).

\section{Pathophysiology of diabetes mellitus}

Diabetes mellitus is a chronic metabolic disorder associated with several complications of the microvascular and macro vascular type. These complications result from several factors but mostly from chronic hyperglycemia in diabetics. Microvascular complications include retinopathy, nephropathy and neuropathy [6]. Macro vascular complications are the most dangerous and often the cause of mortality in diabetics. They include stroke, peripheral vascular complications and myocardial infarction [7]. Oxidative stress characterized by excessive production of reactive oxygen species (ROS) and a decrease in antioxidant substances. This oxidative stress is involved in the occurrence of chronic complications related to diabetes [8].

\section{Antidiabetic drugs}

Antidiabetic drugs aim to control hyperglycemia and relieve symptoms of diabetes, such as polyuria, thirst, ketoacidosis and weight loss. Their action is to reduce blood sugar; they are indicated when the patient has not been able to reduce his blood sugar despite the adoption of a suitable diet, the practice of physical activity and the reduction of risk factors (alcoholism, smoking). The choice of treatment depends on the type of diabetes. For Type I diabetes or insulin-dependent diabetes, insulin is the only choice of treatment; injected insulin acts in the same way as endogenous insulin. 
As for Type 2 Diabetes, the treatment consists of the implementation of hygienic and dietary measures and a pharmacological treatment with oral antidiabetic agents. The first-line therapeutic strategy consists of monotherapy, then if necessary dual therapy or tritherapies may be proposed. After failure of oral polytherapy, the use of insulin will be necessary. These medications either make the pancreas produce more insulin, decrease the absorption of the glucose, help reduce insulin requirements by the body or reduce gluconeogenesis by the liver.

Currently, six classes of oral antidiabetic drugs are available: biguanides, sulfonylureas, meglitinides, thiazolidinediones, dipeptidyl peptidase IV inhibitor, and $\alpha$-glucosidase inhibitors.

\subsection{Biguanides}

Biguanides are derivatives of guanidine, a drug produce by Galega officinalis (lilac of Spain), a plant used from the Middle Ages for its "antidiabetic virtues". The hypoglycemic effect of guanidine was discovered in 1918. Later on, in 1957 metformin named Glucophage or glucose eater was studied in several trials in Paris and showed to lower blood sugar in type 2 diabetics [9]. Now Metformin is the firstchoice treatment for obese patients with type 2 diabetes. The atherosclerotic and cardio protective effects of the drug have been confirmed in prospective and retrospective studies. It is a drug with a very low taste, ideal for all patients and in epidemic progression in emerging countries with low resources. Its main site of action is the liver. Metformin reduces glucose production by lowering gluconeogenesis with the activation of adenosine monophosphate-activated protein kinase in the liver $[10,11]$.

\subsection{Sulfonylureas}

Sulfonylureas are a class of organic compounds used in medicine as antibacterial, antidiabetic and diuretics and also in agriculture. In 1937, began the history of sulfonylureas (SU) with the observation of the antidiabetic effect of synthetic sulfur compounds [12]. Hypoglycemic sulphonamides, or sulphonylureas, stimulate the secretion of insulin by the pancreatic beta cells in sensitizing them to the action of glucose [13].

\subsection{Meglitinides}

Repaglinide and nateglinide are non-sulfonylurea. They act by stimulating the secretion of insulin by ß-pancreatic cells (secretagogue) with the same mechanism of action as sulphonylureas hypoglycemic (inhibition of potassium channels of $B$ pancreatic cells) [14].

\subsection{Thiazolidinediones}

Thiazolidinediones also known as glitazones, contain a functional group in which thiazolidine serves as a dione. They are insulin sensitizers. Glitazones bind and activate a transcription factor called PPAR (Peroxisosme Proliferator-Activated Receptor) and thus inhibiting the secretion of resistingprotein. They have many direct effects on the cardiovascular system. The question of a possible atheroprotective mechanism is currently much debated [15]. 


\subsection{Dipeptidyl peptidase IV inhibitors:}

In 1967, Dipeptidyl peptidase IV inhibitors were discovered; serine protease DPP4 has been a popular subject of research. They inhibit the enzyme dipeptidyl peptidase-4 (DPP-4) [16] which results in an increase of the sensitivity of the beta and alphapancreatic cells to glucose leading to a stimulation of insulin secretion and inhibition of secretion of glucagon only in the presence of a hyperglycemia [17].

\section{6. $\alpha$-glucosidase inhibitors}

The alpha-glucosidases are competitive enzymes necessary to hydrolyze oligo- and polysaccharides into monosaccharides to allow their absorption. $\alpha$-glucosidases inhibitorsslow the absorption of carbohydrates, reducing hyperglycemia and postprandial hyperinsulinemia [18]. Actually these drugs are not widely used because of their need for multiple daily doses, their modest impact, and their gastrointestinal (GI) side effects [19].

\section{Antidiabetic phytochemicals}

Plants are composed entirely of chemicals of various kinds of drugs [20]. One of the remarkable applications of phytotherapy is the use of phytoconstituents for the treatment of diabetes. This practice has fascinated researchers to undertake experiments to study the mechanism of action of these natural remedies and to identify their antidiabetic compounds. Marles and Farnsworth also found that among these plants used traditionally for the treatment of diabetes mellitus, there are those who have been tested experimentally, and $81 \%$ of them showed positive results, which led themto find that these natural remedies represent a potential source for new antidiabetic drugs [21].

In Africa, 185 species are currently used by the population against the diabetes mellitus. On the other hand, in the western region of Algeria, Azziet all identified 60 species, which belong to 32 families. The most cited plants are: Trigonellafoenum-graecum, Rosmarinusofficinalis, Citrullus colocynthis, Tetraclinisarticulata, Artemesiaherbaalba, Origanum compactum, Punicagranatum, Zygophyllum album and Artemisia absinthium [22]. According to Azziet all, the frequent use of these plants, can be explained by their low cost, their availability but also by their efficiency. Ethnobotanical studies report a large number of phytoconstituents that may possess antidiabetic potential, due to the high cost and low availability of current therapies for many rural populations and their minimal side effects. Thus, the management of diabetes without any side effect of oral antidiabetics is still a major challenge. Here is a list of antidiabetic compounds most commonly used in modern folkloric medicine.

\subsection{Allicin}

Allicin is an organosulfur compound found in large quantities in garlic (Allium sativum) and onions (Allium cepa), a species in the family Alliaceae. The allicin molecule is very volatile and has a very short life. It has antimicrobial, antiparasitic and antifungal activities [23], antitumor and antigenotoxic [24]. Allicin hasinhibitory immunomodulatory action [25]. Garlic has a hypoglycemic effect in streptozotocin- as well as alloxan-induced diabetes mellitus in rats and mice [26]. The rapid action of allicin on blood glucose levels appears to be due to an increase in insulin secretion by beta cells of the pancreas. The continuity and increase of its 
effect over time would indicate a decline in insulin resistance that has been demonstrated in animals. This potential effect on insulin resistance looks promising but will need to be verified in other studies [27].

\section{2 .Bakuchiol}

Bakuchiol is a polyphenol compound in the class terpenophenol. It is found in Psoraleacorylifolia and in Otholobiumpubescens [28]. Oral administration of Psoraleacorylifolia extract reduces glucose levels in streptozotocin-induced diabetic mice and increased serum insulin levels [29].

\subsection{Bassic acid}

Bassic acid was found in Bumeliasartorum rootbark. Bassic acid caused significant reduction of glucose levels in alloxan-diabetic rats. In addition, it significantly increased the process of glucose uptake and glycogen synthesis in the isolated rat diaphragm. Basic acid also increases insulin secretion from pancreatic beta cells [30].

\subsection{Berberine}

Berberine is an alkaloid found in such plants as Berberis vulgaris (barberry), Berberis aristata (tree turmeric), Mahonia aquifolium (Oregon grape), which has been used for the treatment of diabetes for thousands of years [31]. Berberine stimulates liver cells, muscle cells and fat cells to absorb glucose through a process that is not dependent on insulin. This function seems to be similar to that of metformin. The activity of berberine increases considerably, when insulin is present. Berberine also helps reduce fat. It can reduce the accumulation of abdominal fat. It seems to perform this activity by decreasing the activity of certain genes that work to form and store more fat $[32,33,34,35,36]$. Berberine also inhibits $\alpha$-glucosidases, an intestinal enzyme. This action causes the intestines to absorb lesser amounts of carbohydrates from the diet, thus leading to low levels of blood sugar after meals $[37,38]$.

\subsection{Caffeine}

Caffeine is an alkaloid found in both leaves and grains of coffee (Coffea arabica, Coffea canefora), tea (Camellia sinensis), cola Colanitida and mate (Ilex paraguariensis) plants [39]. Several epidemiologic researches show that habitual use of caffeine or coffee may help maintain normal glucose tolerance and improve insulin sensitivity $[40,41,42]$. Caffeine decreases glucose and stimulates insulin secretion in vitro and increases glucose uptake in human skeletal muscle cells [43].

\subsection{Catharantine and vindoline}

Catharantine and vindoline are alkaloids produced by the medicinal plant Catharanthus roseus L (Apocynaceae). A decoction of all parts of Catharanthus roseus is well known as an oral hypoglycemic agent. These phytoconstituents show hypoglycemic effect in normal and streptozotocin-induced diabetic rat models. Vindoline, vindolinine and catharanthine, lower blood glucose levels in normal and alloxan diabetic rabbits $[44,45]$.

\subsection{Charantin}

Charantin is steroidal glycoside, found in the fruits of Momordica charantia. Many researchers have reported that charantin is more effective than the oral 
hypoglycemic agent tolbutamide [46]. It has got hypoglycemic property equivalent to insulin [47].

\subsection{Cinnamaldehyde}

Cinnamaldehyde is a flavonoid with the formula $\mathrm{C} 6 \mathrm{H} 5 \mathrm{CH}=\mathrm{CHCHO}$, found in Cinnamon and gives its flavor and odor [48]. In the liver, cinnamaldehyde is metabolized into cinnamic acid before it is absorbed into the blood in rats [49]. Cinnamic acid may beresponsible for hypoglycemic activity of cinnamon. Rahman et all (2015) [50] reported that cinnamic acid exerts antidiabetic activity by increasing glucose uptake and improving insulin sensitivity in adipose and skeletal tissues, thereby improving glycogen synthesis in the liver. Cinnamic compounds have been reported as inhibitors of $\alpha$-glucosidases [51].

\subsection{Curcumin}

Curcumin, bioactive compounds of turmeric, produced by Curcuma longa, a member of the ginger family (Zingiberaceae), is grown throughout Asia, but also in tropical Africa and the West Indies [52]. Human clinical research in diabetic and pre-diabetic patients revealed that curcumin lower serum glucose levels improving the function of pancreatic cells and the oxidation of fatty acids and their use [53]. Articles on animal research reported that curcumin could improve the type 2 diabetic state by the stimulation of increased glucose uptake, increased activation of AMP kinase, suppression of the inflammatory state induced by hyperglycemia and stimulation of insulin secretion from pancreatic tissue [54].

\subsection{D-pinitol(3-O-methyl-chiroinositol)}

D-pinitol, was first identified in the sugar pine Pinus lambertiana [55]. Analogue of D-chiroinositol, obtained in the body by hydrolysis of the lipids of type GPI (glycosylphosphatidylinositol) of the cell membrane, would be a mediator of the action of insulin. It would play a secondary messenger role in translating the insulin signal. It is a possible and potential role of soluble mediator of the action of insulin [56].

\subsection{Emodin}

Emodin is an anthraquinone is a major active component produced by Aloe vera, Emodin has recently been reported to improving insulin sensitivity, lower serum glucose levels, and reverse other symptoms linked to obesity and obesity-related metabolic diseases [57].

\subsection{Gingerol}

Gingerol is a phenolic compound found in ginger (Zingiberofficinale) a medicinal plant having anti-nausea, anti-inflammatory, and anti-tumor properties. Many studies have reported that administration of 1,600 to $3,000 \mathrm{mg}$ of ginger powder daily for 8 to 12 weeks reduced fasting serum glucose levels and HbA1c levels in type 2 diabetics., The 6-gingerol may be the responsible for the hyperglycemic effect. The mechanism by which gingerol improves glucose tolerance remains uncertain $[58,59]$.

\subsection{Ginsenosides}

Ginsenosides are ginseng saponins and are found almost exclusively in the plant genus Panax (ginseng). These active substances are recognized as neuroprotectives, 
antioxidants and effective stimulants of the immune system [60]. Many studies reported that ginseng helps to control blood glucose levels but do not solve the problem-no pancreatic $\beta$-cell function. Ginsenosides have significant hypoglycemic activity and anti-obesity properties, improve muscle metabolism and reduce inflammation through increase $\mathrm{C}$-reactive protein levels in a diabetic mouse model [61].

\subsection{Glycyrrhizin}

Glycyrrhizin is extracted from the root of licorice Glycyrrhiza glabra. The natural licorice juice contains 5 to $20 \%$. It is a glycoside known primarily for its sweet flavor, hence its use as a sweetener. Studies in mice have shown that glycyrrhizin not only reduces blood sugar levels but also acts as an anti-inflammatory. It offers other therapeutic benefits since it can also preventsteatos is an accumulation of fat called triglyceride in liver cells [62].

\subsection{Gymnemic acids, gymnemagenin, gymnestrogenin}

Gymnemic acids, gymnemagenin, gymnestrogeninare a mixture of glycosides isolated from the leaves of Gymnemasylvestre (Asclepiadaceae) which has the property of masking the sweet taste. The plant exhibits an effective natural remedy for diabetes. It increases the insulin producing beta-cells of pancreas and significantly reduces the metabolic effects of sugar [63, 64].

\subsection{Inulin}

Inulins are polysaccharides produced naturally by many types of plants such as onions, garlic, chicory root, banana and wheat. They belong to a class of dietary fiber called fructans [65]. Digestion does not convert inulin into monosaccharide, it does not raise blood glucose and is useful in the management of diabetes [66]. Inulin exerts a hypoglycemic effect that is not accompanied by a change in insulin levels, suggesting an improvement in insulin sensitivity; this effect could be explained in part by the decrease in disaccharidases activity [67, 68].

\subsection{Isoorientin}

Isoorientin is a flavone, a chemical flavonoid. It is the luteolin-6-C-glycoside. It can be isolated from Gentianaolivieri, Vitex egundo, Terminalia myriocarpa, and Swertia japonica. It was shown to reduce plasmatic glucose, cholesterol, and triglyceride concentrations in streptozotocin-induced diabetic rats [69]. The mechanisms mediating the antidiabetic properties of ISO are still unknown although results obtained with animal models and clinical trials rule out the possibility that these properties may be due to insulin-secreting effects or modulation of the intestinal absorption of glucose [70].

\subsection{Kaempferol-3-neohesperidoside}

Kaempferol-3-neohesperidoside is a bitter-tasting flavonoid glycoside. It can be found in Cyatheaphalerata Mart. It exhibits an insulin-like activity and is thus potential "insulin mimetic [71].

\subsection{Mahanimbine}

Mahanimbine is a carbazole alkaloid found in leaves, stem bark and Murrayakoenigiiroot, family Rutaceae [72]. 
The hypoglycemic effect of mahanimbinemay be due to potentiating of insulin effect either by increasing the pancreatic secretion of insulin from beta cells or by increasing the peripheral glucose uptake [73].

\subsection{Momordicine I, Momordicine II}

MomordicineI, MomordicineII were isolated from Momordica charantia. Both compounds showed significant insulin releasing activity in MIN6 $\beta$-cells at concentration of 10 and $25 \mu \mathrm{g} / \mathrm{Ml}$ [74].

\subsection{Naringin}

The naringin is a flavonoid found naturally in citrus fruits. Naringenin has hypoglycemic activity by inhibiting $\alpha$-glucosidases and thus suppressing carbohydrate absorption from the intestine, thereby increasing the blood glucose levels [75].

\subsection{Oleanolic acid}

Oleanolic acid is a pentacyclic triterpenes especially isolated from the olive leaf. Oleanolic acid is relatively non-toxic, has various pharmacological properties, such as hepatoprotective and anti-tumor effects [76]. Oleanolic acid inhibits $\alpha-$ glucosidases in vitro, improves the insulin response, reverse the functionality and survival of $\beta$ cells and protects against diabetes complications $[77,78]$.

\subsection{Polypeptide-p}

The p-polypeptide was isolated from Momordica charantia (The bitter melon) is one of the most commonly used vegetables to control diabetes. Trigonellafoenumgraecum is the second source containing the P-polypeptide [79]. The Polypeptide-p is an insulin-like hypoglycemic protein that reduces blood glucose levels in humans when injected subcutaneously [80]. P-insulin works by mimicking the action of human insulin in the body and can therefore be used as a substitute for herbal insulin in patients with type 1 diabetes.

\subsection{Quercetin}

Quercetin is flavonoids, found in many fruits, vegetables, leaves, and grains [81]. Authors have shown a role for quercetin in the regulation of hepatic gene expression and lipid metabolism. The antidiabetic qualities of quercetin involve the stimulation of glucose uptake through an MAPK (Mitogen-Activated Protein Kinase) insulindependent [82] mechanism. Quercetin has shown to help decrease the seriousness of numbness, jolting pain, and irritation for patients with type 2 diabetes neuropathy. It has further been shown that active treatment with quercetin can improve various quality-of-life matrices [83].

\subsection{Shikonin}

Shikonin is a major red naphthoquinone pigment that can be isolated from the root of Lithospermumerythrorhizon [84]. Numerous studies have demonstrated that shikonin has a variety of clinical effects, including antimicrobial effects [85] antioxidant effects [86] and proliferative effects in wound healing [87]. It is an antiallergenic agent [88] and has anti-cancer effects [89,90]. Shikonin increases glucose absorption in 3T3-L1 adipocyte cells, primary rat adipocytes and cardiomyocytes by increasing both insulin signaling and increasing glucose uptake by itself, and by 
inhibiting fat accumulation in 3T3-L1 adipocytes. Mechanisms by which shikonin increases glucose uptake in adipocytes are not fully understood [91].

\subsection{Steviol}

Steviol is a diterpene first was found in the plant Stevia rebaudiana in 1931. Steviol occurs in the plant as steviol glycosides. It has an intensely sweet flavor [92]. Results suggest that stevioside and related compounds affect plasma glucose-mediated insulin secretion and sensitivity, which enhance glucose removal from plasma [93]. Stevioside also inhibits gluconeogenesis in the liver of diabetic rats [94].

\subsection{Trans-dehydrocrotonin}

Trans-Dehydrocrotonin, is a diterpene found in the bark of Croton cajucaraBenth (Euphorbiaceae). Previous studies have shown significant hypoglycemic activity in alloxan-induced diabetic rats but not in normal rats at oral doses of 25 and $50 \mathrm{mg} /$ $\mathrm{kg}$ body weight. This compounds also effectively decreased blood sugar levels in normal glucose-fed rats [95].

\subsection{Trigonelline}

Trigonelline originally extracted from the seeds of Trigonellafoenumgraecum (Fenugreek a member of family Leguminosae (Fabaceae) is a commonly used spice in India, Middle East, Egypt, and NorthAfrica [96]. Earlier reports indicate that trigonelline reduces blood glucose concentrations in ratsand in human [97]. Trigonelline protects $\beta$-cells of the pancreas and increases insulin sensitivity index as well as insulin content [98].

Table 1 Antidiabetic drugs isolated from antidiabetic plants

\begin{tabular}{|l|l|l|}
\hline Compounds & Plants & References \\
\hline Allicin & Allium sativum ; Allium cepa & {$[\mathbf{2 6 , 2 7}]$} \\
\hline Bakuchiol & $\begin{array}{l}\text { Psoralea corylifolia ; Otholobium } \\
\text { pubescens }\end{array}$ & {$[\mathbf{2 9}]$} \\
\hline Bassic acid & Bumelia sartorum & {$[\mathbf{3 0}]$} \\
\hline Berberine & Berberis vulgaris ; Berberis aristata & {$[\mathbf{3 2 , 3 3 , 3 4 , 3 5 , 3 6 ]}$} \\
\hline Caffeine & Coffea L & {$[\mathbf{4 0 , 4 1 , 4 2 , 4 3}]$} \\
\hline Catharantine and vindoline & Catharanthus roseus L & {$[\mathbf{4 4 , 4 5 ]}$} \\
\hline Charantin & Momordica charantia & {$[\mathbf{4 6 , 4 7 ]}$} \\
\hline Cinnamaldehyde & Cinnamomum & {$[\mathbf{4 9 , 5 0 , 5 1 ]}$} \\
\hline Curcumin & Curcuma longa & {$[\mathbf{5 3 , 5 4}]$} \\
\hline D-pinitol \\
chiroinositol) & Pinus lambertiana & {$[\mathbf{5 5 , 5 6}]$} \\
\hline Emodin & & {$[\mathbf{5 7}]$} \\
\hline Gingerol & Aloe vera & {$[\mathbf{5 8 , 5 9 ]}$} \\
\hline Ginsenosides & Zingiber officinale & {$[\mathbf{6 0 , 6 1}]$} \\
\hline Glycyrrhizin & Panax ginseng & {$[\mathbf{6 3}]$} \\
\hline Gymnemic acids, & Glycyrrhiza glabra & \\
\hline
\end{tabular}


Medical Technologies Journal, Volume: 2, Issue: 2, April-June 2018, Pages: 199-214. Doi : https://doi.org/10.26415/2572-004X-vol2iss1p199-214

\begin{tabular}{|l|l|l|}
\hline $\begin{array}{l}\text { gymnemagenin, } \\
\text { gymnestrogenin }\end{array}$ & & \\
\hline Inulin & Allium sativum; Allium cepa & {$[\mathbf{6 7 , 6 8}]$} \\
\hline Isoorientin & Gentiana olivieri; Vitex egundo & {$[\mathbf{7 0 ]}$} \\
\hline $\begin{array}{l}\text { Kaempferol-3- } \\
\text { neohesperidoside }\end{array}$ & Cyathea phalerata & {$[\mathbf{7 1}]$} \\
\hline Mahanimbine & Murraya koenigii & {$[\mathbf{7 3}]$} \\
\hline $\begin{array}{l}\text { Momordicine I } \\
\text { Momordicine II }\end{array}$ & Momordica charantia & {$[\mathbf{7 4 ]}$} \\
\hline Naringin & Citrus fruits & {$[\mathbf{7 5 ]}$} \\
\hline Oleanolic acid & Olea europaea & {$[\mathbf{7 7 , 7 8}]$} \\
\hline Polypeptide-p & $\begin{array}{l}\text { Momordica charantia; Trigonella } \\
\text { foenumgraecum }\end{array}$ & {$[\mathbf{8 0 ]}$} \\
\hline Quercetin & $\begin{array}{l}\text { Allium cepa;Malus pumila ; Citrus } \\
\text { fruits }\end{array}$ & {$[\mathbf{8 2 , 8 3 ]}$} \\
\hline Shikonin & Lithospermum erythrorhizon & {$[\mathbf{8 9 , 9 0 , 9 1 ]}$} \\
\hline Steviol & Stevia rebaudiana & {$[\mathbf{9 3 , 9 4 ]}$} \\
\hline Trans-dehydrocrotonin & Croton cajucara & {$[\mathbf{9 5}]$} \\
\hline Trigonelline & Trigonella foenumgraecum & {$[\mathbf{9 6 , 9 7 , 9 8 ]}$} \\
\hline & & \\
\hline
\end{tabular}

\section{Conclusion}

This review adds more data to those previously published researches by other authors, as there are many plants, which have hypoglycemic effects. Several reviews have collectively described the anti-diabetic and hypo-lipidemic properties of many natural products, although in many cases the components and cellular mechanisms responsible for the bioactivity have not been elucidated. In this research, rat and mice are the most common animals model used to investigate the Antidiabetic bioactive compounds from plants. There is an urgent need to document traditional knowledge, as the current rate of urbanization can lead to the permanent loss of this valuable knowledge. Phytoconstituents can be used as alternatives to antidiabetic drugs in diabetes medications because they have no proven side effects and may help reduce the costs associated with treatment of diabetes mellitus. More researches are needed in order to extract and separate the antidiabetic components from plants and molecular interactions of their compounds to investigate their cellular mechanism and their toxicity.

\section{Funding}

Organizations that have funded this research: none. 


\title{
8. Conflict of interest statement
}

The authors declare that they have no conflict of interest.

\section{Authors' biography}

\author{
No Biography
}

\section{References}

[1] Li WL, Zheng HC, Bukuru J, De KimpeN.Natural medicines used in the traditional Chinese medical system for therapy of diabetes mellitus.J Ethnopharmacol2004; 92(1):1-21. https://doi.org/10.1016/j.jep.2003.12.031 PMid:15099842

[2] Huang THW, Peng G, Kota BP, Li GQ, Yamahara J, Roufogalis BD et al. Anti-diabetic action of Punicagranatum flower extract: activation of PPAR-c and identification of an active

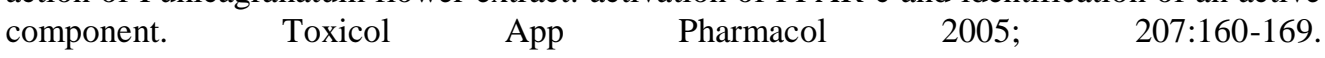
https://doi.org/10.1016/j.taap.2004.12.009 PMid:16102567

[3] Bailey, CJ, Turner, RC. Metformin. N Engl J Med 1996; 334:574-579. https://doi.org/10.1056/NEJM199602293340906 PMid:8569826

[4] Saxena A, VikramNK.Role of selected Indian plants in management of type 2 diabetes: a review.JAltern Complement Med 2004; https://doi.org/10.1089/107555304323062365 PMid:15165418

[5] Jung M, Park M, Lee HC, Kang YH, Kang ES, Kim SK. Antidiabetic agents from medicinal plants. Curr Med Chem 2006; 13: 1203-18. https://doi.org/10.2174/092986706776360860 PMid: 16719780

[6] Fujioka K. Pathophysiology of type 2 diabetes and the role of incretin hormones and betacell dysfunction. JAAPA 2007; suppl 3-8.

[7]Holt G I. Diagnosis, epidemiology and pathogenesis of diabetes mellitus an update for Psychiatrists. Br. J. Psychiatry 2004; 184:55- s63. https://doi.org/10.1192/bjp.184.47.s55

[8] Patel DK, Kumar R, Laloo D, Hemalatha S. Evaluation of phytochemical and antioxidant activities of the different fractions of Hybanthusenneaspermus (Linn.) F. Muell. (Violaceae). Asian Pac J Trop Med 2011; 4(5): 391-6. https://doi.org/10.1016/S1995-7645(11)60110-7

[9] Cusi, K, Defronzo, RA. Metformin: a review of its metabolic effects. Diabetes Reviews 1998; 6:89-131.

[10] Viollet B, Guigas B, Garcia N, Leclerc J, Foretz M, Andreelli F. Cellular and molecular mechanisms of metfromin: an overview. ClinSci 2012; 122(6):253-70. doi:10.1042/CS20110386. https://doi.org/10.1042/CS20110386

[11] Jarald E, Joshi SB, Jain DCH. Diabetes and herbal medicines. Iran J pharm \&Therap 2008; 7(1): 97-106.

[12] Levine R: Sulfonylureas: background and development of the field. Diabetes Care.19847 (Suppl. 1):3-7,

[13] Daniele Sola, Luca Rossi, GianPieroCarnevaleSchianca, Pamela Maffioli, Marcello Bigliocca , Roberto Mella , Francesca Corlianò , Gian Paolo Fra, EttoreBartoli , Giuseppe Derosa3,4 Sulfonylureas and their use in clinical practice. Arch Med Sci 2015; 11. 4: 840-848, DOI: $10.5114 /$ aoms.2015.53304.

[14]. Blicklé JF. Meglitinide analogues: a review of clinical data focused on recent trials. Diabetes Metab 2006r;32(2):113-120. https://doi.org/10.1016/S1262-3636(07)70257-4

[15]. Inzucchi SE, Bergenstal RM, Buse JB, Diamant M, Farrannini E, Nauck M, Peters A, Tsapas A, Wender R, Mathhews DR: Management of hyperglycemia in type 2 diabetes: a patient-centered approach: position statement of the American Diabetes Association (ADA) and the European Association for the Study of Diabetes (EASD). Diabetes Care 2012; 35:13641379. https://doi.org/10.2337/dc12-0413 PMid:22517736 PMCid:PMC3357214

[16] Green, Brian; Flatt, Peter; Bailey, Clifford "Dipeptidyl peptidase IV (DPP IV) inhibitors: a newly emerging drug class for the treatment of type 2 diabetes", Diabetes and vascular disease research2013; 3 (3): 159-165, https://doi.org/10.3132/dvdr.2006.024

[17] Sebokova, Elena; Christ, Andreas; Boehringer, Markus; Mizrahi, Jacques, "Dipeptidyl peptidase IV inhibitors: The next generation of new promising therapies for the management of 
type 2 diabetes", Current Topics in Medicinal Chemistry 2006 ;7 (6): 547-555, doi:10.2174/156802607780091019.

[18] White JR: Overview of the medications used to treat type 2 diabetes. In Medications for the Treatment of Diabetes. White JR, Campbell RK, Eds. Alexandria. Va., American Diabetes Association 2008;5-15. PMCid:PMC2288590

[19] Inzucchi SE, Bergenstal RM, Buse JB, Diamant M, Farrannini E, Nauck M, Peters A, Tsapas A, Wender R, Mathhews DR: Management of hyperglycemia in type 2 diabetes: a patient-centered approach: position statement of the American Diabetes Association (ADA) and the European Association for the Study of Diabetes (EASD). Diabetes Care 2012; 35:13641379.

https://doi.org/10.2337/dc12-0413 PMid:22517736 PMCid:PMC3357214

[20] Breslin, Andrew: "The Chemical Composition of Green Plants". Sciencing, Leaf Group Ltd; 2017.

[21] Harborne, Jeffrey B.; Baxter, Herbert; Moss, Gerard P., eds. "General Introduct". Phytochemical dictionary a handbook of bioactive compounds from plants (2nded.). London: Taylor \& Francis 1999. vii. ISBN 9780203483756.

[22] Eric Block "The chemistry of garlic and onions". Scientific American. 1985; 252 :114-9. https://doi.org/10.1038/scientificamerican0385-114 PMid:3975593

[23] Bagria P, Alia M, Aeria V, Bhowmikb M, Sultanaa S. Anti-diabetic effect of Punicagranatum flowers: Effect on hyperlipidemia, pancreatic cells lipid peroxidation and antioxidant enzymes in experimental diabetes. Food ChemToxicol 2009; 47(1): 50-4.

https://doi.org/10.1016/j.fct.2008.09.058 PMid:18950673

[24] Siddique YH, Afzal M. Antigenotoxic effect of allicin against SCEs induced by methyl methanesulphonate in cultured mammalian cells. Indian J ExpBiol 2004; 42: 437-438.

PMid:15088697

[25] Lang A, Lahav M, Sakhnini E, et al. Allicin inhibits spontaneous and TNF-alpha induced secretion of proinflammatory cytokines and chemokines from intestinal epithelial cells. ClinNutr 2004; 23: 1199-1208. https://doi.org/10.1016/j.clnu.2004.03.011 PMid:15380914

[26] Padiya R and Banerjee SK. Garlic as an anti-diabetic agent: recent progress and patent reviews. Recent Pat Food NutrAgric2013; 127. https://doi.org/10.2174/18761429113059990002

PMid:23270395

[27] Muhamed Osman, Ariza Adnan, NorSalmahBakar, FatmaAlashkham. Allicin has significant effect on autoimmune anti-islet cell antibodies in type 1 diabetic rats. Pol $\mathrm{j}$ pathol 2012; 63: 248-254.

https://doi.org/10.5114/pjp.2012.32772 PMid:23359194

[28]BalaramanManohar, SoundarDivakar and KadimiUdayaSankar, Bull .Amyloglucosidase Catalyzed Syntheses of Bakuchiol Glycosides in Supercritical Carbon Dioxide.. Korean Chem. Soc2009;. 30:.1760-1766.

[29] Seo E, Lee EK, Lee CS, Chun KH, Lee MY, Jun HS. Psoraleacorylifolia L. seed extract ameliorates streptozotocin-induced diabetes in mice by inhibition of oxidative stress. Oxid Med Cell Longev. 2014;2014:897296. doi: 10.1155/2014/897296.

[30] Naik SR, Barbosa Filho JM, Dhuley JN, Deshmukh V. Probable mechanism of hypoglycemic activity of bassic acid, a natural product isolated from Bumeliasartorum. J Ethnopharmacol 1991;33(1-2):37-44. https://doi.org/10.1016/0378-8741(91)90158-A

[31] Yin J, Xing H, J Ye. Efficacy of berberine in patients with type 2 diabetes mellitus Metabolism 2008; 712-717. https://doi.org/10.1016/j.metabol.2008.01.013 PMid:18442638 PMCid:PMC2410097

[32] Y Zhang, X Li, D Zou, W Liu, J Yang, N Zhu, Treatment of type 2 diabetes and dyslipidemia with the natural plant alkaloid berberine. J ClinEndocrinolMetab 2008;. 25592565. https://doi.org/10.1210/jc.2007-2404 PMid:18397984

[33] YS Lee, WS Kim, KH Kim, MJ Yoon, HJ Cho, Y Shen, et al. Berberine, a natural plant product, activates AMP-activated protein kinase with beneficial metabolic effects in diabetic and insulin-resistant statesDiabetes 2006;5: 2256-2264.

[34] Yin J, Chen M, Tang J, Li F, Zhou L, Yang Y. Effects of berberine on glucose and lipid metabolism in animal experiment. Chin J Diabetes2004;12 : 215-218.

[35] Leng SH, LuFE, Xu LJ. Therapeutic effects of berberine in impaired glucose tolerance rats and its influence on insulin secretion.ActaPharmacol Sin2004; 25: 496-502. PMid:15066220 
[36] Tang LQ, Wei W, Chen LM, Liu S. Effects of berberine on diabetes induced by alloxan and a high-fat/high-cholesterol diet in ratsJEthnopharmacol2006;108:109-115.

[37] Dong H, Zhao Y, Zhao L, Lu F ."The effects of berberine on blood lipids: a systemic review and meta-analysis of randomized controlled trials". Planta Med 2013;79 (6): 437-46. doi:10.1055/s-0032-1328321. PMID 23512497. https://doi.org/10.1055/s-0032-1328321

[38] Liu CS, Zheng YR, Zhang YF, Long XY."Research progress on berberine with a special focus on its oral bioavailability". Fitoterapia (Review) 2016; 109: 274-82. doi:10.1016/j.fitote.2016.02.001. https://doi.org/10.1016/j.fitote.2016.02.001

[39] Nehlig A, Daval JL, DebryG."Caffeine and the central nervous system: mechanisms of action, biochemical, metabolic and psychostimulant effects". Brain Research. Brain Research Reviews $1992 ; \quad 17 \quad$ (2): $139-70 . \quad$ doi:10.1016/0165-0173(92)90012-B. https://doi.org/10.1016/0165-0173(92)90012-B

[40] Pereira MA, Parker ED, Folsom AR. Coffee consumption and risk of type 2 diabetes mellitus: an 11-year prospective study of 28,812 postmenopausal women. Arch Intern Med 2006;166:1311-6. https://doi.org/10.1001/archinte.166.12.1311 PMid:16801515

[41] Yamaji T, Mizoue T, Tabata S, Ogawa S, Yamaguchi K, Shimizu E, et al. Coffee consumption and glucose tolerance status in middle-aged Japanese men. Diabetologia 2004;47:2145-51. https://doi.org/10.1007/s00125-004-1590-5 PMid:15662555

[42] Bidel S, Hu G, Sundvall J, Kaprio J, Tuomilehto J. Effects of coffee consumption on glucose tolerance, serum glucose and insulin levels- a crosssectional analysis. HormMetab Res 2006;38:38-43. https://doi.org/10.1055/s-2006-924982 PMid:16477539

[43] Monteiro M, Farah A, Perrone D, Trugo LC, Donangelo C. Chlorogenic acid compounds from coffee are differentially absorbed and metabolized in humans. J Nutr 2007;137:2196-201. https://doi.org/10.1093/jn/137.10.2196 PMid:17884997

[44] Chattopadhyay, R.R. A comparative evaluation of some blood sugar lowering agents of plant origin. J. Ethnopharmacol 1999; 67: 367-372. https://doi.org/10.1016/S03788741(99)00095-1

[45] Yao XG1, Chen F, Li P, Quan L, Chen J, Yu L, Ding H, Li C, Chen L, Gao Z, Wan P, Hu L, Jiang H, Shen X . Natural product vindoline stimulates insulin secretion and efficiently ameliorates glucose homeostasis in diabetic murine models. J Ethnopharmacol 2013;28 :150(1):285-97. doi: 10.1016/j.jep.2013.08.043.

[46]Cousens G. There is a cure for diabetes: the tree of life 21day program. California: North Atlantic Books 2008; 191-192.

[47] Jayasooriya AP, Sakono M, Yukizaki C, Kawano M, Yamamoto K, Fukuda N. Effects of Momordicacharantia powder on serum glucose levels and various lipid parameters in rats fed with cholesterol-free and cholesterol-enriched diets. J Ethnopharmacol 2000; 72(1- 2):331-336. [48] Gutzeit, Herwig.Plant Natural Products: Synthesis, Biological Functions and Practical Applications. Wiley 2014; 19-21. ISBN 978-3-527-33230-4.

[49] Chen, Y., Ma, Y., Ma, W. Pharmacokinetics and bioavailability of cinnamic acid after oral administration of Ramuluscinnamomi in rats. Eur. J. Drug Metab.Pharmacokinet. 2009; 34, $51-$ 56.

https://doi.org/10.1007/BF03191384 PMid:19462929

[50] Rahman M. Hafizur, Abdul Hameeda, MishkatShukrana, Sayed Ali Razaa, Sidra Chishti, NurulKabir, Rehan A. Siddiqui a. Cinnamic acid exerts anti-diabetic activity by improving glucose tolerance in vivo and by stimulating insulin secretion in vitro. Phytomedicine2015; 22: 297-300. https://doi.org/10.1016/j.phymed.2015.01.003 PMid:25765836

[51] Adisakwattana S., Sookkongwaree, K., Roengsumran, S., Petsom, A., Ngamrojnavanich, N., Chavasiri, W., Deesamer, S., and Yibchok-anun, S.Structure-Activity Relationships of trans-Cinnamic Acid Derivates on Alpha Glukosidase Inhibition, Bioorg. Med. Chem.Lett 2007;14: 2893-2896. https://doi.org/10.1016/j.bmcl.2004.03.037 PMid:15125954

[52] Majeed, Shaheen. "The State of the Curcumin Market". Natural Products Insider 2015.

[53] Honnalagere Ramesh Puneeth, AngatahallyChandrashekariahSharada. Antidiabetic effects of a series of curcuminpyrazoles in-vitro.Asian $\mathrm{j}$ pharm clin res 2015; 6: 146-149.

[54] Seo K.-I., Choi M.-S., Jung U. J. Effect of curcumin supplementation on blood glucose, plasma insulin, and glucose homeostasis related enzyme activities in diabetic $\mathrm{db} / \mathrm{db}$ mice," Molecular Nutrition and Food Research2008;52: 995- 1004, https://doi.org/10.1002/mnfr.200700184 PMid:18398869 
[55]Anderson, A. B.; MacDonald, D. L.; Fischer, H. O. L. The Structure of Pinitol. Journal of the American Chemical Society 1952; 74 (6): 1479. doi:10.1021/ja01126a036. https://doi.org/10.1021/ja01126a036

[56]Sarah H Bates, Robert B Jones, Clifford J Bailey. Insulin-like effect of pinitol.Br J Pharmacol2000; 130(8): 1944-1948. https://doi.org/10.1038/sj.bjp.0703523 PMid:10952686 PMCid:PMC1572278

[57] Feng, Y, Huang, S.L, Dou, W, Zhang, S,Chen, J.H, Shen, Y, Shen, J.H,Leng, Y. Emodin, a natural product, selectively inhibits 11 beta-hydroxysteroid dehydrogenase type 1 and ameliorates metabolic disorder in diet-induced obese mice. Br. J. Pharmacol 2010;161: 113 126. https://doi.org/10.1111/j.1476-5381.2010.00826.x PMid:20718744 PMCid:PMC2962821

[58] Islam, M.S. and Choi, H. Comparative effects of dietary ginger (Zingiberofficinale) and garlic (Allium sativum) investigated in a type 2 diabetes model of rats. J Med Food. 2008; 11 : 152-159. https://doi.org/10.1089/jmf.2007.634 PMid:18361751

[59] Singh A.B,Akanksha S.N, Maurya R, and Srivastava A.K. Anti-hyperglycemic, lipid lowering, and anti-oxidant properties of [6]-gingerol in db/db mice. Int J Med Med Sci. 2009; 1: 536-544.

[60] Vuksan V, Sievenpiper JL, Koo VY, Francis T, Beljan-Zdravkovic U, Xu Z, Vidgen E American ginseng (Panaxquinquefolius L) reduces postprandial glycemia in nondiabetic subjects and subjects with type 2 diabetes mellitus.Arch Intern Med2000;160(7):1009-13. https://doi.org/10.1001/archinte.160.7.1009 PMid:10761967

[61] Sievenpiper JL, Arnason JT, Vidgen E, Leiter LA, Vuksan V.A systematic quantitative analysis of the literature of the high variability in ginseng (Panax spp.): should ginseng be

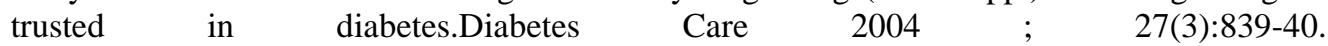
https://doi.org/10.2337/diacare.27.3.839-a PMid:14988315

[62]SubhrojitSen, MoumitaRoy,AbhaySankarChakraborti. Ameliorative effects of glycyrrhizin on streptozotocin-induced diabetes in rats.Pharmacy and pharmacology 2011, 63: 287-296. DOI: $10.1111 /$ j.2042-7158.2010.01217.x.

[63].Bishayee A, and Chatterjee, M.Hypolipidaemic and antiatherosclerotic effects of oral Gymnemasylvestre R. Br. Leaf extract in albino rats fed on a high fat diet. Phytothera.Res 1994; 8: 118-120. https://doi.org/10.1002/ptr.2650080216

[64]PragyaTiwari, B. N. Mishra, and Neelam S. Sangwan . Phytochemical and Pharmacological Properties of Gymnemasylvestre: An Important Medicinal Plant Biomed Res Int 2014; 830285. DOI: $10.1155 / 2014 / 830285$.

[65] Kolida S, Gibson GR. Prebiotic capacity of inulin-type fructans. J Nutr. 2007;137(11 Suppl):2503S-2506S. https://doi.org/10.1093/jn/137.11.2503S PMid:17951493

[66] Cherbut C. Motor effects of short-chain fatty acids and lactate in the gastrointestinal tract. ProcNutr Soc. 2003;62:95-99. https://doi.org/10.1079/PNS2002213

[67] Cani PD, Knauf C, Iglesias MA, Drucker DJ, Delzenne NM, Burcelin R. Improvement of glucose tolerance and hepatic insulin sensitivity by oligofructose requires a functional glucagon-like peptide 1 receptor. Diabetes 2006;55:1484-1490. https://doi.org/10.2337/db051360 PMid:16644709

[68] Cani PD, Daubioul CA, Reusens B, Remacle C, Catillon G, Delzenne NM. Involvement of endogenous glucagon-like peptide-1(7-36) amide on glycaemia-lowering effect of oligofructose in streptozotocin-treated rats. $J$ Endocrinol2005;185:457-465. https://doi.org/10.1677/joe.1.06100 PMid:15930172

[69] Revilla-Monsalve MC Andrade-Cetto A Palomino-Garibay MA, Wiedenfeld H .IslasAndrade S.Hypoglycemic effect of Cecropiaobtusifolia Bertol aqueous extracts on type 2 diabetic patients. J Ethnopharmacol ;2007:111 .636-640.

[70] Shibano M , Kakutani K, Taniguchi M Yasuda M, Baba K .Antioxidant constituents in the dayflower (Commelinacommunis L.) and their $\alpha$-glucosidase-inhibitory activity. J Nat Med. 2008; 62 :349 -353 https://doi.org/10.1007/s11418-008-0244-1 PMid:18409066

[71] Zanatta L.; Rosso Â.; Folador P.; Figueiredo M. S. R. B.; Pizzolatti M. G.; Leite L. D.; Silva F. R. M. B. Insulinomimetic effect of kaempferol 3-neohesperidoside on the rat soleus muscle. J. Nat. Prod 2008; 71: 532-535. https://doi.org/10.1021/np070358 PMid:18303854

[72] Knolker HJ, Reddy KR. Isolation and synthesis of biologically active carbazole alkaloids. Chem Rev 2002; 102: 4303-4427. https://doi.org/10.1021/cr020059j

[72]Dineshkumar.B, AnalavaMitra, ManjunathaMahadevappa. Antidiabetic and hypolipidemic effects of mahanimbine (carbazole alkaloid) from murrayakoenigii (rutaceae) leaves. International Journal of Phytomedicine2010; 2: 22-30. 
[74] Keller AC, Ma J, Kavalier A, He K, Brillantes AM, Kennelly EJ. Saponins from the traditional medicinal plant Momordicacharantia stimulate insulin secretion in vitro. Phytomedicine. 2011;19:32-37. https://doi.org/10.1016/j.phymed.2011.06.019 PMid:22133295 PMCid:PMC3389550

[75] Ortiz-Andrade RR, Sánchez-Salgado JC, Navarrete-Vázquez G, Webster SP, Binnie M, García-Jiménez S, León-Rivera I, Cigarroa-Vázquez P, Villalobos-Molina R, Estrada-Soto S Antidiabetic and toxicological evaluations of naringenin in normoglycaemic and NIDDM rat models and its implications on extra-pancreatic glucose regulation. DiabetesObesMetab2008; 10(11):1097-104. https://doi.org/10.1111/j.1463-1326.2008.00869.x PMid:18355329

[76] Liu J.Pharmacology of oleanolic acid and ursolic acid. Journal of Ethnopharmacology. 1995; 49 (2): 57-68. doi:10.1016/0378-8741(95)90032-2. https://doi.org/10.1016/03788741(95)90032-2

[77] Hou W, Li Y, Zhang Q. Triterpene acids isolated from Lagerstroemia speciosa leaves as $\alpha$-glucosidase inhibitors. Phytother Res 2009;23:614-618 . https://doi.org/10.1002/ptr.2661 PMid: 19107840

[78] Komaki E, Yamaguchi S, Maru I, et al. Identification of Anti-Amylase Components from Olive Leaf Extracts. Food SciTechnol Res 2003;9:35-39 https://doi.org/10.3136/fstr.9.35

[79] Hellolife .Plypeptide-P (plant insulin)- A natural treatment for diabetes. The smart living network. http://www.smartlivingnetwork.com/diabetes/b/polypeptide-p-plant-insulin-anatural-treatment-for-diabetes.

[80] Tayyab F, Lal SS, Mishra M, Kumar U. A review: Medicinal plants and its impact on diabetes. World J Pharm Res 2012;1(4):1019-1046.

[81] Punithavathi VR, Prince PSM.Combined effects of quercetin and $\alpha$-tocopherol on lipids and glycoprotein components in isoproterenol induced myocardial infarcted Wistar rats. $\begin{array}{llll}\text { Chemico-Biological } & \text { Interactions } & 2009 ; & 181:\end{array}$ https://doi.org/10.1016/j.cbi.2009.07.002 PMid:19595682

[82] ValensiP, Le Devehat C.,. Richard J.-L,A multicenter, double-blind, safety study of QR333 for the treatment of symptomatic diabetic peripheral neuropathy: a preliminary report. Journal of Diabetes and Its Complications 2005; 19:247-253. https://doi.org/10.1016/j.jdiacomp.2005.05.011 PMid:16112498

[83] P. Haddad, H. Eid, A. Nachar, F. Thong, and G. Sweeney, "The molecular basis of the antidiabetic action of quercetin in cultured skeletal muscle cells and hepatocytes," Pharmacognosy Magazine 2015;41: 74. https://doi.org/10.4103/0973-1296.149708 PMid:25709214 PMCid:PMC4329636

[84] Papageorgiou V P, Assimopoulou A N, Couladouros E A, Hepworth D. \&Nicolaou K. C. The chemistry and biology of alkannin, shikonin, and related naphthazarin natural products. AngewandteChemie International Edition 1999; 38: 270-300. https://doi.org/10.1002/(SICI)1521-3773(19990201)38:3<270::AID-ANIE270>3.0.CO;2-0

[85] Brigham LA, Michaels PJ, Flores HE.Cell-specific production and antimicrobial activity of naphthoquinones in roots of lithospermumerythrorhizon. Plant Physiol 1999; 119(2):417-28. https://doi.org/10.1104/pp.119.2.417 PMid:9952436 PMCid:PMC32117

[86] Han J., Weng X. \& Bi K. Antioxidants from a Chinese medicinal herbLithospermumerythrorhizon. Food Chemistry 2008;106: 2-10. https://doi.org/10.1016/j.foodchem.2007.01.031

[87] Lu PJ, Yang C, Lin CN, Li CF, Chu CC, Wang JJ, Chen JY.Shiunko and acetylshikonin promote reepithelialization, angiogenesis, and granulation tissue formation in wounded skin.Am J Chin Med 2008; 36(1):115-23. https://doi.org/10.1142/S0192415X08005631 PMid:18306455

[88] Lee CC, Wang CN, Lai YT, Kang JJ, Liao JW, Chiang BL, Chen HC, Cheng YW Shikonin inhibits maturation of bone marrow-derived dendritic cells and suppresses allergic airway inflammation in a murine model of asthma. $\mathrm{Br} \mathrm{J}$ Pharmacol2010; 161(7):1496-511. https://doi.org/10.1111/j.1476-5381.2010.00972.x PMid:20735407 PMCid:PMC3010563

[89] Fu Z, Deng B, Liao Y, Shan L, Yin F, Wang Z, Zeng H, Zuo D, Hua Y, CaiZ.The antitumor effect of shikonin on osteosarcoma by inducing RIP1 and RIP3 dependent necroptosis.BMC Cancer 2013; 13:580. https://doi.org/10.1186/1471-2407-13-580 PMid:24314238 PMCid:PMC4028842

[90] Liang D, Sun Y, Shen Y, Li F, Song X, Zhou E, Zhao F, Liu Z, Fu Y, Guo M, Zhang N, Yang Z, Cao Y. Shikonin exerts anti-inflammatory effects in a murine model of lipopolysaccharide-induced acute lung injury by inhibiting the nuclear factor-kappaB signaling 
pathway. $\quad$ IntImmunopharmacol2013;

https://doi.org/10.1016/j.intimp.2013.04.020 PMid:23651796

$16(4): 475-80$.

[91] Kamei R, Kitagawa Y, Kadokura M, Hattori F, Hazeki O, Ebina Y, Nishihara T, Oikawa S. Shikonin stimulates glucose uptake in 3T3-L1 adipocytes via an insulin-independent tyrosine kinase pathway. BiochemBiophys Res Commun 2002; 292(3):642-51. https://doi.org/10.1006/bbrc.2002.6714 PMid:11922615

[92] Brandle J E ,Starratt A N M,Gijzen. Stevia rebaudiana: Its agricultural, biological, and chemical properties. Canadian Journal of Plant Science 1998; 78: 527-536. DOI:10.4141/P97114. https://doi.org/10.4141/P97-114

[93] Lailerd N, Saengsirisuwan V, Sloniger JA, Toskulkao C, Henriksen EJ.Effects of stevioside on glucose transport activity in insulin-sensitive and insulin-resistant rat skeletal muscle. Metabolism 2004; 53(1):101-7. https://doi.org/10.1016/j.metabol.2003.07.014 PMid:14681850

[94] Chen TH, Chen SC, Chan P, Chu YL, Yang HY, Cheng. Mechanism of the hypoglycemic effect of stevioside, a glycoside of Stevia rebaudiana.JT.Planta Med2005; 71(2):108-13. https://doi.org/10.1055/s-2005-837775 PMid:15729617

[95]R. A. F. Farias , V. S. N. Rao , G. S. B. Viana , E. R. Silveira , M. A. M. Maciel , A. C. Pino Hypoglycemic Effect of trans-Dehydrocrotonin, a Nor-ClerodaneDiterpene from Croton cajucara.PlantaMed 1997; 63(6): 558-560.DOI: 10.1055/s-2006-957766.

[96]El-Abhar HS, Schaalan MF. Phytotherapy in diabetes: Review on potential mechanistic perspectives. World J Diabetes 2014; 5(2): 1 https://doi.org/10.4239/wjd.v5.i2.176

[97]Grover JK, Yadav S, Vats V. Medicinal plants of India with antidiabetic potential. J Ethnopharmacol 2002; 81(1): 81-100. https://doi.org/10.1016/S0378-8741(02)00059-4

[98]Van Dijk, A.E., et al., Acute effects of decaffeinated coffee and the major coffee components chlorogenic acid and trigonelline on glucose tolerance. Diabetes Care, 2009; 32(6): 1023-1025. https://doi.org/10.2337/dc09-0207 PMid:19324944 PMCid:PMC2681030 